\title{
Publications on Grundtvig and Grundtvigianism available through Grundtvig-Selskabet, Vartov
}

Grundtvig-Studier 1979-81: DKK 50.00.

Grundtvig-Studier 1982-87: DKK 75.00.

Grundtvig-Studier 1988: DKK 125.00.

Grundtvig-Studier 1989-94: DKK 150.00.

Grundtvig-Studier 1995-96: DKK 160.00.

Grundtvig-Studier 1997-2004: DKK 170.00.

N. F. S. Grundtvig: Danne-Virke (facsimile, 1983): DKK 300.00.

N. F. S. Grundtvig: Sangvark bd. 6 (Kommentarbind; facsimile, 1983): DKK 20.00.

Glenthøj, Elisabeth A., Glenthøj, Johannes B., Holm, Jette, Kallesen, Leif og Toftdahl, Lars i samarbejde med Thodberg, Christian: Grundtvig. Proedikener i Vartov, 1839-42, bind 1-4, inkl. kommentarbind (bind 4), København, Vartov (2003): DKK 123.00 pr. bind.

Glenthøj, Elisabeth A. og Holm, Jette i samarbejde med Christian Thodberg: Grundtvig. Proedikener $i$ Vartov, 1843-45, bind 5-8, inkl. kommentarbind (bind 8), København, Vartov (2007): DKK 123.00 pr. bind.

Grønbæk, Villiam (1951), Psykologiske tanker og teorier hos Grundtvig: DKK 15.00.

Høirup, Henning (1955), Frederik Lange Grundtvig: DKK 15.00.

Johansen, Steen (1956), Taler på Marielyst: DKK 20.00 .

Kofoed, Niels (1954), Grundtvig som selvbiograf: DKK 20.00.

Nielsen, Jens A. (1961), Grundtvig og Gisselfeld: DKK 15.00.

Scharling, C. I. (1947), Grundtvig og romantikken: DKK 15.00.

Toldberg, Helge (1946), Grundtvig som filolog: DKK 15.00 .

Weltzer, Carl (1952), Grundtvig og Søren Kierkegaard: DKK 15.00.

Orders should be placed with Grundtvig-Selskabet, Vartov, Farvergade 27, DK-1463 132 København $K$, giro 7057598, tel.: +45 33732800, e-mail: kg@vartov.dk, website: http://www.vartov.dk.

Please note that postage for dispatch is extra. 


\section{Publications of Grundtvig-Selskabet and other select publications \\ still in print. (Roman numerals indicate the serial number in Grundtvig- Selskabet's list)}

XXVII A. M. Allchin, N. F. S. Grundtvig. An Introduction to his Life and Work. Darton, Longman \& Todd, London; Aarhus University Press, Århus 1997. $338 \mathrm{pp}$. May be purchased through booksellers or direct from Aarhus University Press. DKK 298.00.

XXVIII S. A. J. Bradley, N. F. S. Grundtvig's Transcriptions of the Exeter Book. Grundtvig Archive Fascicle 316, 1-8 in the Royal Library Copenhagen. An Analysis. Supplement to the Registrant over N. F. S. Grundtvigs Papirer. Copenhagen 1998. $77 \mathrm{pp}$. May be purchased through the Centre for Grundtvig Studies, Aarhus University. DKK 50.00.

XXIX Helge Grell, Vision og virkeliggørelse. En redegørelse for Grundtvigs tanker om folkelig oplysning og en folkelig højskole og for forsøget på at virkelig gøre dem. Center for Grundtvig Studier, Aarhus Universitet, in commission with Aarhus University Press, Aarhus. 154 pp. May be purchased through booksellers or direct from Aarhus University Press. DKK 150.00.

XXXI Bent Christensen, Omkring Grundtvigs vidskab. En undersøgelse af N. F. S. Grundtvigs forhold til den erkendelsesmoessige side af det kristeligt nødvendige livsengagement. Gads Forlag, København 1998. 630 pp. May be purchased through booksellers. DKK 325.00.

XXXII Ole Vind, Grundtvigs historiefilosofi. Gyldendal, Copenhagen 1999. 645 pp. May be purchased through booksellers. DKK 300.00.

XXXIII A. M. Allchin et al. (eds), Grundtvig in International Perspective. Studies in the Creativity of Interaction. Aarhus University Press, Århus 2000. 209 pp. May be purchased through booksellers or direct from Aarhus University Press. DKK 248.00.

XXXIV Anders Holm, Historie og efterklang: En studie i N. F. S. Grundtvigs tidsskrift Danne-Virke. Odense Universitetsforlag, Odense 2001. 139 pp. May be purchased through booksellers or direct from Odense Universitetsforlag. DKK 175.00.

XXXV Knud Eyvin Bugge, Grundtvig og slavesagen. Aarhus Universitetsforlag, Århus 2004. 226 pp. May be purchased through booksellers or direct from Aarhus Universitetsforlag. DKK 228.00.

XXXVI Claus Bjørn, Grundtvig som politiker - Udgivet af Thorkild C. Lyby. Forlaget Anis, København, 2007, 264 pp. May be purchased through booksellers or direct from Forlaget Anis. DKK 295.00.

XXXVII S. A. J. Bradley, N. F. S. Grundtvig: A Life Recalled. An Anthology of Biographical Source-Texts. Aarhus University Press, Århus 2007, 600 pp. May be purchased through booksellers or direct from Aarhus University Press. DKK 500.00.

XXXVIII Regner Birkelund, Frihed til foelles bedste: En oppositionel stemme fra fortiden - om Grundtvigs frihedsbegreb, Århus 2008, 685 pp. May be purchased through booksellers or direct from Aarhus University Press. DKK 448.00 . 


\section{Grundtvig-Studier 2008}

Volume 59 of the Grundtvig Society's annual journal.

In this, the 225th anniversary year of Grundtvig's birth and the 60th anniversary year of this journal, Grundtvig-Studier 2008 presents its usual broad range of articles, comprising literary-critical and literaryhistorical studies and hymnological and theological conceptual analyses. Included are a major original edition of Grundtvig's RimBrev til Nordiske Paarørende (1832) and also the publication of a hitherto unprinted letter from Grundtvig to G. P. Brammer. Accommodation of the growing international interest in Grundtvig is sustained by an English-language study of Grundtvig's handling of the AngloSaxon Exeter Book riddles and (in Danish) an analytical survey of the reception of Grundtvig's hymns and songs among Danish settlers in America.

$* * *$

Bind 59 af Grundtvig-Selskabets årbog.

2008 er 225-året for Grundtvigs fødsel og markerer samtidig Grundtvig-Studiers 60 års jubilæum. Årbogen præsenterer traditionen tro Grundtvig fra både litterære, hymnologiske og historiske synsvinkler. Grundtvigs Rim-Brev til Nordiske Paarørende genoptrykkes med grundige kommentarer og efterskrift, og et lille, hidtil ukendt brev fra N. F. S. Grundtvig til G. P. Brammer offentliggøres med en efterskrift. De senere års bestræbelser på at inddrage den voksende internationale interesse for Grundtvig føres videre $i$ form af en analyse (på engelsk) af hans arbejde med gåderne i den oldengelske Exeterbog og i et indlæg om hans salmers og sanges receptionshistorie i USA. 